\title{
Nyctanthes arbor-tristis: A Wonder Indian Herbal Drug Needs Healthcare Attention
}

\author{
Reema Srivastava ${ }^{1}$, Deepali Trivedii ${ }^{1}$, Gauri Shukla ${ }^{1}$ and Pankaj Srivastava*2 \\ ${ }^{1}$ Deparment of Botany, Kanoria Mahila Mahavidyalaya, India \\ ${ }^{2}$ Department of Laparoscopic, Thoracic, Thoracoscopic and VATS Surgeon, Om Surgical Center \& Maternity Home, India
}

Received: May 31, 2018; Published: June 11, 2018

*Corresponding author: Pankaj Srivastava, Department of Laparoscopic, Thoracic, Thoracoscopic \& VATS Surgeon, Om Surgical Center \& Maternity Home, SA 17/3, P-4, Sri Krishna Nagar, Paharia, Ghazipur Road, Varanasi, UP, PIN-221007, India

\begin{abstract}
Researchers have been investigating new active principles from time tested plants which have been used as medicinal remedies through the ages by the native people. Nyctanthus arbor-tristis (NA) Linn. is also very useful traditional medicinal plant of India, which has been cultivated for ornamental use and medicine as well. It is distributed throughout in sub-Himalayan regions and southwards to Godavari. Virtually each part of the plant has some medicinal value and is thus investigated extensively. It has been traditionally used to treat many ailments. We have tried to do a review of the existing literature and to present the entire work in a very comprehensive manner. We have also emphasized that more extensive research is warranted to proper exploration of this wonder medicinal plant as it is very cheap and widely distributed.
\end{abstract}

Keywords: Nyctanthus; Flavonoids; Phytochemical; Anti-Panosomal; Diuretic; Indian Herb

Abbreviations: PO: Peroral; SC: Subcutaneous; EMCV: Encephalo Myo Carditis Virus; SFV: Semliki Forest Virus; SOD: Superoxide Dismutase; CAT: Catalase; SGPT: Serum Glutamic Pyruvic Transaminase; SGOT: Serum Glutamic Oxaloacetic Transaminase

\section{Introduction}

Nyctanthus arbor-tristis Linn. (Oleaceae) is popularly known as 'Night Jasmine' or 'Harsinghar' (Hindi) due to the fact that is flowers emit a very strong and pleasant fragrance during the whole night $[1,2]$. The flowers start falling after midnight and by the day break, the plant appears dull. The generic name 'Nyctanthus' has been coined from two Greek words 'Nykhta' (Night) and 'anthos' (flower) [3,4]. The specific name 'arbor-tristis' meaning 'the sad tree' is supposedly derived from dull looks of the tree during daytime [5]. It is a terrestrial woody perennial having life span of 5-20 years. The shrub grows to a height of 10 meters. The simple leaves are opposite, with an entire margin about $6-12 \mathrm{~cm}$ long and $2-6.5 \mathrm{~cm}$ wide. The flowers are fragrant with a five to eight lobed corolla and orange- red centre, often seen in a cluster of 2 to 7 . The fruit is flat, brown and heart-shaped to rounded capsule, around $2 \mathrm{~cm}$ in diameter with two sections, each containing a single seed. Nyctanthus is commonly known as:
a. Night flowering jasmine
b. Coral jasmine
c. Parijat in Hindi
d. Paariijaatham in Telgu

\section{e. Shephali in Oriya}

\section{Plant perspective}

In its native habitat, Nyctanthus arbour-tristis is found on rocky ground in dry hillsides and as undergrowth in dry deciduous forests. It is native to southern Asia, stretching across northern Pakistan and Nepal through northern India to southeast Thailand. It grows at sea level up to $1500 \mathrm{~m}$ altitude, within a wide range of rainfall patterns from seasonal to non-seasonal and is tolerant to moderate shade. In India it is found in outer Himalayas, Jammu, Nepal, Tripura, flowering usually from July to October. The Plant has been classified as follows:
a. Kingdom
Plantae
b. (Unranked)
Angiosperms
c. (Unranked)
Eudicots
d. (Unranked)
Asterids
e. Order
Lamiales
f. Family
Oleaceae
g. Genus 

h. Species
arbor-tristis
i. Binomial name :
Nyctanthus arbor-tristis

\section{Phytochemistry}

Phytochemistryanalysis ofleaf, fruit and seeds of NA revealed the presence of phytosterols, phenolics, tannins, flavonoids, glycosides and saponins. The secondary metabolites such as glycosides and alkaloids are the largest groups of chemicals produced by this plant [6,7]. Extracts of the seeds, flowers and leaves possesses immunostimulant, hepatoprotective, antileishmanial, antiviral and antifungal activities in-vitro. The bark contains a glycoside and two alkaloids, one soluble in water and the other soluble in chloroform. Its roots are composed of alkaloids, tannins and glucosides. The glycosides are iridoid glycosides and phenylpropanoid glycosides [8-10], Iridoid glucosides, arbortristoside A, B, D and E have been isolated from seeds [11-13]. The mannitol is abundantly found in the flower of NA. Flower contain a modified diterpenoidnycanthin, flavonoids, anthocyanins and essential oil which is similar to jasmine (9). Stem of NA contains glycoside - naringenin 4'-0-B-glucapyranosyl-cc-xylopyranoside and B-sitosterol [14-15].

\section{Medicinal Usage}

Virtually all parts of the plant have been used in different diseases and in different indications. By and large, different parts have following activities like:

a. Leaves - antibacterial, anti-inflammatory, anti-fungal, anti-pyretic

b. Flowers - anti-filarial, antioxidant, diuretic

c. Seeds - antifungal, antibacterial, antileishmanial, immunomodulatory

d. Stem - antipyretic and antioxidant

e. Bark - anti-microbial

f. Flower oil - as perfume

\section{Pharmacologic Activities}

Biological activity of NA has been reported from the crude extracts and their different fractions from leaf, bark, root, seed, oil [16-18]. Crude extracts of different parts of NA have been used as traditional medicine for the treatment of various diseases. Use of different parts of NA in Ayurveda, Siddha and Unani systems of medicines has been prescribed from time immemorial [19-21]. Traditionally the powdered stem bark is given in rheumatic joints pain, in treatment of malaria and also as expectorant. The plant has been screened for antihistaminic activity, CNS activity (i.e. hypnotic, tranquillizing, anesthetics), analgesic, anti-inflammatory, antipyretic, antiulcer, amebicidal, anthelmintic, antipanosomal to antidepressants, antiviral and immunomodulatory activities $[22,23]$.

Antioxidant Activity: Nyctanthus arbor-tristis revealed the presence of flavonoids, tannins, saponins, glycosides, alkaloids, steroids and phenolic compounds. Phenolic compounds have been recognized as antioxidant agents, which act as free radical terminators [24-26]. Phytochemical screenings of the ethanolic extract of the leaves and stems of aqueous and alcoholic extracts of dried leaves of NA also have adequate antioxidant activity. The encouraging results of NA with the various in vitro antioxidant tests proved the plant as a reducing agent and effective as scavenger of hydrogen peroxide and free radicals. The overall antioxidant activity of NA might be attributed to its polyphenolic content and other phytochemical constituents [26].

Anticancer Activity: The anticancer activity of NA was first reported by Khatune et al. who have found petroleum ether, chloroform and ethyl acetate extracts of flowers to exhibit significant cytotoxic activity [14]. Recently, methanolic extract of stem bark has been reported to exhibit significant anticancer activity in comparison to 5-fluorouracil against Dalton's ascetic lymphoma in Swiss albino rats [9].

Immuno-Stimulant Activity: Plant extracts have been widely investigated for their possible immunomodulatory properties [27]. Aqueous leaf extract of NA has been found as a potent immunomodulator as evidenced by both humoral and cell mediated responses [28,29]. Flowers have also been shown to possess immuno-stimulant activity by activating the cell mediated immune system [28]. The ethanolic seed and root extracts of NA also showed immunomodulatory activity against systemic candidiasis in mice.

Hepatoprotective Activity: Ethanolic leaf extract of NA protect against carbon tetrachloride-induced hepatotoxicity in root. For this investigation roots were protected with extract $(1000 \mathrm{mg} / \mathrm{kg})$ body weight / day, Peroral (PO) for 7 days) prior to the administration of a single dose of $\mathrm{ccl}_{4}(1.0 \mathrm{ml} / \mathrm{kg})$ subcutaneous (SC). The samples of blood were collected at 48 hour after $\mathrm{ccl}_{4}$ administration ( 9 day) from the abdominal aorta under pentabarbitone anesthetized (350mg/kg) silymarin (70 mg/kg body weight / day PO for 7 days) were used as a reference standard. The mechanism involves the blockade of bio-activation of (CCl4) through inhibition of p450 2E1 activity and or to accelerate the detoxification of $\left(\mathrm{ccl}_{4}\right)$. These affects may be mediated by the antioxidant present in the plant. In other investigation, the ethanolic and aqueous extract of the leaf of NA (500mg/kg PO for 10 days) reversed the rise in serum AST and total bilirubin in $\left(\mathrm{Ccl}_{4}\right)$ induced hepatotoxicity in animal model [30].

Antiviral Activity: The ethanolic extract, n-butanol fractions and two pure compounds, arbortristoside C, isolated from the NA possess pronounced inhibitory activity against encephalomyocarditis virus (EMCV) and Semliki forest virus (SFV). The in-vivo ethanolic extract and the n-butanol fraction at daily doses of $125 \mathrm{mg} / \mathrm{kg}$ weight protected EMCV infected mice against SFV by 40 and $60 \%$ respectively [31].

Antimicrobial And Antifungal Activities here And Should be and Phenolic compounds and tannins in ethanolic extract of leaves are found to be active against Staphylococcus aureus and Salmonella paratyphi. Antimicrobial evaluation of aqueous and alcoholic extract of leaves against numerous gram positive and gram negative stains revealed that Salmonella typhimurium, 
Pseudomonas aeruginosa, Klebsiella pneumonia, E.coli, P.marginata and Staphylococcus epidermis were found more susceptible to the aqueous extract whereas Micrococcus luteus, Staphylococcus aureus, Streptococcus pyogenes, and Bacillus subtilis were more sensitive to methanolic extract. Chloroform and ethyl acetate extracts of fresh and dried leaf, flowers, fruit and seeds are also reported to have a dose-dependent antibacterial activity against gram negative bacteria. The activity has been found significant for fresh plant materials than the dried plant parts. The stem bark extracts (petroleum ether, chloroform and ethanol) are found to have potential antimicrobial activity against S. aureus, Micrococcus luteus, B.subtilis, E.coli, P.aeruginosa, Candida albicans and Aspergillus niger [32,33].

Anti-Allergy Activity: The pretreatment of guinea pigs exposed to histamine aerosol with a water soluble portion of the alcoholic extract of NA leaves offered significant protection against the development of asphyxia [34]. Arbortistoside A and arbortristoside C present in NA were reported to be anti-allergic [26].

Anti-Diabetic Activity: Oral administration of chloroform extracts of leaf and flower and 50\% ethanolic extract of leaves significantly increase superoxide dismutase (SOD) and catalase (CAT) levels and cause a significant reduction in liver lacto peroxidase (LPO), serum levels of SGPT, SGOT, alkaline phosphatase, cholesterol and triglyceride levels in comparison to the diabetic controls. Ethanol extract of the stem bark also possess significant anti-diabetic activity when treated in streptozotocinnicotinamide induced diabetic rats. The extract lowers the blood glucose level in a dose-dependent manner $[35,36]$.

Anticholinesterase Activity: The aqueous extract of NA stimulated the activity of acetylcholinesterase in mice; it antagonizes the inhibition of this enzyme by malathion. The higher effects were seen in the brain [37]. The low anti-muscarinic activity against acetylcholine induced contractions of isolated rabbit ileum was already reported [38].

Miscellaneous Activities: Acetone extract of the seeds exhibit ovicidal effect on the eggs of rice moth, Corcyra cephalonica. The inhibition of egg hatching increased with increase in concentration of plant extracts in contact toxicity test. $80-73 \%$ ovicidal action was observed at $100 \%$ concentration of the extract. Petroleum ether extract of NA also exhibits insecticidal activity against Bagradacruciferarum. The ethanolic extract of NA leaves, seed and roots were scanned portion of an ethanol extract of the leaves exhibit significant aspirin like antinociceptive activity but failed to produce morphine like analgesia.

\section{Conclusion}

NA easily available and no special conditions are required for its collection and cultivation. It is a valuable medicinal plant and a unique source of useful metabolites such as alkaloids, phytosterols, phenolics, tannins, flavonoids, glycosides and saponins. For the last few years, there has been an increasing awareness for NA research. Several therapeutically and industrially useful preparations and compounds have also been marketed, which generates enough encouragement among the scientists in exploring more information about their medicinal plant. Potential of this plant in management of various diseases makes it a plant of clinical interest. Though plant has been found to be safe but the potent curvature effects of the plant against particular human ailment need to be verified by more controlled and exhaustive clinical trials.

\section{References}

1. Siddiqquil Ania M, JahanAA (2006) Rapid multiplication of Nyctanthus arbor-tristis through in-vitro auxillary shoots proliferation. world journal of agricultural science 34: 188-192.

2. Rout GR, Mahoto A, Senapati SK (2007) In vitro clonal propagation of Nyctanthus arbortristis Linn- a medicinal tree. Horticulture science (prague) 34(2): 84-89.

3. Vats M, Sharma N, Sardana S (2009) Antimicrobial activity of stem bark extracts of Nyctanthus arbortristis Linn. (Oleaceae) International Journal of pharmacognosy and Phytochemical Research 1(1): 12-14

4. Meshram MM, Rangari SB, Kshirsagar SB, Gajbiye S, Trivedi MR, et al. (2012) Nyctanthus arbortristis. A herbal panacea. International Journal of pharmaceutical sciences and research 3(8): 2432-2440.

5. Suresh V, Jaikumar S, Arunachalam G (2010) Antidiabetic activity of ethanolic extract of stem bark of Nyctanthusarbortristis Linn. Research journal of pharmaceutical, biological and chemical sciences 1(4): 311317.

6. Dhingra VK, Seshadri TR, Mukherjee SK (1976) Carotenoid glycosides of Nyctanthusarbor-tristis Linn. Ind J chem 14: 231.

7. Kapoor LD, Kapoor SL, Shrivastava SN, Singh A, Sharma PC (1971) Survey of Indian plants for saponins, alkaloids and flavonoids II. Llyoida 34(1): 94-102.

8. Tuntiwachwuttikul P, Rayanil K, Taylor WC (2003) Chemical constituents from the flowers of Nyctanthusarbor-tristis. science asia 29: 21-30.

9. Khatune $\mathrm{Na}$, Islam ME, Adbur Rahman MA, Mosaddik MA, Haque HE (2003) In vivo cytotoxic evaluation of a new benzofuran derivative isolated from Nyctanthusarbor-tristis. L on ehrlichascite carcinoma cells (EAC) in mice. J Med sci 3(2): 169-173.

10. Patra A, Mathur V, kundu AB (1997) A phenyl propanoid glycoside from Nyctanthusarbor-tristis Linn. J Ind chem Soc 74(8): 653-655.

11. Rathore A, Srivastava V, Srivastava KC, tendon J (1990) Iridoid glucosides from Nyctanthusarbor-tristisphytochemistry 29(6): 1917-1920.

12. Mathuram V, Kundu AB (1991) A reinvestigation of the structures of arbortristosides A and B from Nyctanthusarbor-tristis. J Nat proct 54(1): 257-260.

13. Purus Othman KK, Venkata Narasimhan M, Sarada A (1985) Arbortristoside A and B, two iridoidglucosides from Nyctanthusarbortristis. Phytochemistry 24(4): 773-776.

14. Khatune NA, Haque ME, Mosaddik MA, Haque ME (2001) Antibacterial activity and cytotoxicity of Nyctanthusarbortristis flower. Fitoterapia 72(4): 412-414.

15. Dseshmukh RD, Pokharkar RD, Takate SB and Gik VN (2007) Amelioration of ccl4 induced hepatosuppression by Nyctanthusarbortristis Linn. leaves in wistar albino rates. Pharmacology online 203-208.

16. Sabio M, Raviprakash V, Suresh S and Jawahar L (1974) Pharmacological actions of Nyctanthusarbor-tristis, proc $6^{\text {th }}$ annual conf. Ind pharm Soc Indian pharmacol 6: 17.

17. Surange SR, Pendse GS (1971) Pharmacognostic study of leaf of Nyctanthusarbor-tristis Linn (parijiata). I Res Ind Med 6(4): 183-190. 
18. Mandal S, P Jain R, Mukhopadhyay S (1998) Naturally occurring iridoids with pharmacological activity. Indian J pharm sci 60(3): 123-127.

19. Girach RD, aminuddin SA, Siddiqui PA, khan SA (1994) Ethanomedicinal studies on harsinghar (Nyctanthusarbor-tristis 2)-a less known medicinal plant in unani medicine. hamdard Med 37(2): 60-66.

20. Pant R (1983) Nyctanthusarbor-tristis. Sachitraayurved 35(9): 613-615

21. Goyal DK, Tiwari SK, Agarwal R (1997) Effect of Parijata leaves on sciatica. sachitraayurved 51: 667-668.

22. Sasmal D, Das S, Basu SP (2007) phytoconstituents and therapeutic potential of Nyctanthusarbor-tristis Linn. pharmacog rev 1(2): 344-349.

23. Dharmadhikari SD, Shrivastava MP, Dashputra PG (1986) Study of analgesic property of Nyctanthusarbor-tristis (prajaht). Ind J pharmacol 18(1): 19-60.

24. Shahidi F, Wanasundra PKJPD (1992) phenolic antioxidants. Crit Rev food Sci Nutr 32(1): 67-103.

25. Devasagayam TPA, Sainis KB (2002) Immune system and antioxidants, especially those derived from Indian medicinal plants. Indian J exp boil $40(6)$ : 639-655.

26. Rathee JS, Hassarajani SA, Chattopadhyay S (2007) antioxidant activity of Nyctanthusarbor-tristis leaf extract. food chem 103(4): 1350-1357.

27. Alamgir M and Uddin SJ (2010) Recent advances on the Ethanomedicinal plants as immunomodulatory agents. Ethanomedicine: In a source of complementary therapeutics, (Eds.). by chattopadhyay D, Research Signpost, Kerala, India pp. 227-244.

28. Puri A, Saxena RP, Saxena R, Saxena KC, Tandon JS, Srivastava V (1994) Immunostimulant activity of Nyctanthusarbor-tristis L. Ethanopharmacolgy 42(1): 31-37.

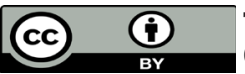

This work is licensed under Creative Commons Attribution 4.0 License

Submission Link: https://biomedres.us/submit-manuscript.php
29. Bhatia A, Kaur J (2001) Nyctanthusarbor-tristis leaves extract as antagonize of Immunotoxic effects of chemical pesticides (experimental study). Intern J environ studies 58.

30. Rathee JS, Hassarjani SA, Chattopadhyay S (2001) Antioxidant activity of Nyctanthusarbortristis leaf extract. Food chemistry 103(4): 1350-1357.

31. Surekha B Barwal, Mohammed Shakir Ghouse, Amruta S Wattamwar, Ajit M Murkute (2017) A Comprehensive Review on Night-flowering Jasmine Nyctanthes arbor-tristis. Journal of Medical and Pharmaceutical Innovation 4(19): 1-6.

32. Aggarwal SG, Goyal S (2013) Nyctanthusarbor-tristis against Pathogenic Bacteria. Journal of Pharmacognosy and phytochemistry 2(3): 124-127.

33. Geetha DH, Rajeshwari M (2014) Anti-bacterial activity of leaf of Nyctanthus Linn. International Research Journal of Nyctanthusarbortristis Linn. International Research Journal of Pharmaceutical and applied sciences 4(4): 4-6.

34. Saxena RS, Gupta B, Lata S (2002) Tranquilizing, antihistaminic and puragative activity of Nyctanthusarbor-tristis leaf extract. J ethanopharmacol 81(3): 321-325.

35. Sharma V, Pooja Marwaha A (2011) Hypoglycemic activity of methanolic extract of Nyctanthusarbortristis Linn. root in alloxan induced diabetic rats. International Journal of Pharmacy and Pharmaceutical Sciences 3(3): 210-212.

36. Paatanayak C, Datta PP, Chauhan AS, Firdousch KA, Prasad A, et al. (2012) Hypoglycaemic effect of Nyctanthusarbortristis leaf extract on alloxan induced diabetic rats. American journal of pharmtech research 2(6): 380-387.

37. Verma N, Kaur J, Bhatia A (2001) Stimulation of acetyl cholinesterase activity with Nyctanthusarbortristis leaves extract in the melathiontreated immunosuppressed mice. Int J environ studies 58: 645-654.

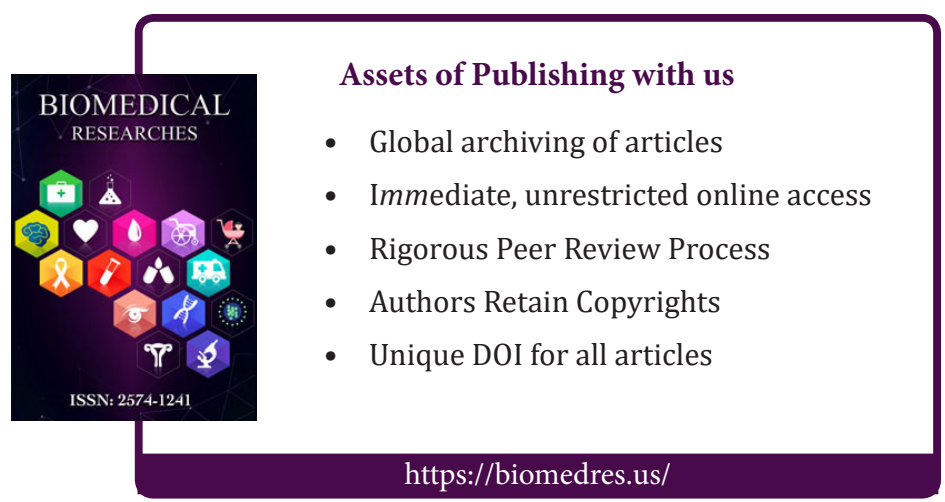

